(C) 2014

Yevstafieva V. O., Doctor of Veterinary Science

Poltava State Agrarian Academy

\title{
EFFICIENCY OF THE FLOTATION COPROOVOSCOPICAL INTRAVITAL DIAGNOSTIC METHODS OF PROTOZOOSES AND NEMATODOSES OF PIGS
}

\section{Reviewer is Doctor of Veterinary Science M. Skrypka}

\begin{abstract}
Представлені результати визначення видового складу паразитозів свиней у господарствах Полтавської області (Полтавський, Диканський, Карлівський райони) та ефективності флотаційних методів їх діагностики. Внаслідок копроовоскопічних досліджень встановлені збудники гельмінтозів (аскароз, езофагостомоз, трихуроз) $і$ протозоозів (еймеріози, балантидіоз). Флотаиійні методи дослідження із застосуванням бішофіту та Котельникова-Хренова показали високу ефективність у процесі діагностики аскарозу, езофагостомозу, еймеріозів і балантидіозу відповідно.
\end{abstract}

Keywords: pigs, eymerioses, balantydiosis, askarosis, tryhurosis, ezophagostomosis, flotation diagnostic methods, efficiency.

Statement of the problem. Among the most important concepts that are general biological importance leading parasitism and parasitic system. Parasitism - a very widespread phenomenon in nature. Different branches of the phylogenetic he formed independently and recorded all the kingdoms of the organic world and subkingdoms. The largest number of parasitic species in the animal kingdom is registered among the simplest organisms, worms and arthropods. The number of species of parasitic organisms according to different authors varies from $6-7 \%$ to $50 \%$ of the total number of animals $[2,4]$. According to a number of domestic and foreign researchers parasitic diseases are widespread in pig farms, especially associative invasions [9-11]. Therefore, the efficiency of different intravital methods of diagnosis parasites in pigs remains questionable.

Analysis of major studies and publications which discuss the problem. A successful fight against intestinal parasites depends on proper and timely diagnosis. For the clinical signs of these diseases is difficult to identify because in most cases they are not specific. Therefore, when a diagnosis on protozooses and helminthoses of pigs important to a comprehensive approach. This takes into account epizootological data, clinical signs, pathological-anatomical changes and the results of laboratory studies $[3,6]$. The final stage of diagnosis is to detect oocysts, cysts of the protozoa and helminth eggs in stool samples, selected from animals by microscopic studies [1].

Now for diagnosis protozooses used: for previous, tentative survey - methods native smear and flotation (qualitative methods) and for the individual, to determine the severity of the disease flotation and flotation-centrifuge (quantitative methods) [5].

Most researchers, academics and professionals using qualitative methods, which include flotation: a Darling's method (S. Darling, 1911), Fyulleborn's method (F. Fulleborn, 1920), E. Kalantarian's method (1938), A. Shcherbovych's method (1952), Kotelnykov-Khrenov's method (1978) and their modifications $[7,8]$.

Aims and objectives of the research. The aim of the study was to investigate the efficiency of flotation coproovoscopical intravital methods of protozooses and helminthoses of pigs. The task was to determine the species composition of parasites of pigs and installation of diagnostic efficiency by flotation using different flotation

Materials and methods of the research. Research conducted during the winter and spring 2014 based pig farms of the Poltava region (Poltava, Dykanka, Karlivka areas) with different ownership and laboratory of parasitology and veterinary-sanitary examination of Poltava State Agrarian Academy. To detect helminthoses and protozooses been studied 280 stool samples from pigs of different sex and age groups, quantitative method for V. Trach. Diagnosis is established based on the detection of parasite eggs in the material. In order to establish the diagnostic efficiency of flotation methods used most famous and widespread methods of research: Fyulleborn's method - with a solution of salt, Kotelnykov-Khrenov's method - with ammonium nitrate solution and using bishofit. Calculated the number of pathogens detected in $1 \mathrm{~g}$ of feces.

Results. In the study of the species composition of parasitosis in pig farms Poltava region found that animals infected by nematodes: Ascaris suum, Oesophagostomum dentatum, Trichuris suis, protozoa of the genus Eimeria species and Balantidium suis (Table 1). 
ВЕТЕРИНАРНА МЕДИЦИНА

1. Comparative efficiency research flotation methods $(n=18)$

\begin{tabular}{|c|c|c|c|c|c|}
\hline \multirow[b]{2}{*}{ The method of investigation } & \multicolumn{5}{|c|}{ Extensity of invasion, \% } \\
\hline & $\begin{array}{l}\frac{n}{\infty} \\
0 \\
\frac{0}{3} \\
\frac{\pi}{4} \\
\frac{1}{4}\end{array}$ & 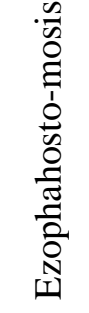 & 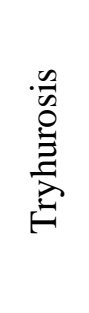 & 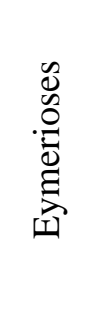 & 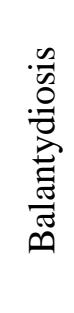 \\
\hline Fyulleborn's & 37,5 & 81,3 & 12,5 & 43,8 & 12,5 \\
\hline Kotelnykov-Khrenov's & 37,5 & 87,5 & 12,5 & 37,5 & 56,3 \\
\hline From the solution bishofit & 50 & 93,8 & - & 62,5 & 18,8 \\
\hline
\end{tabular}

2. Indicators of the intensity protozoa and helmintosic infestations of pigs by different research methods $(n=18)$

\begin{tabular}{|c|c|c|c|c|c|}
\hline \multirow[b]{2}{*}{ The method of investigation } & \multicolumn{5}{|c|}{$\begin{array}{c}\text { The intensity of infestation, M } \\
\text { (eggs, oocysts, cysts in } 1 \mathrm{~g} \text { faeces - EGF, OGF, CGF) }\end{array}$} \\
\hline & 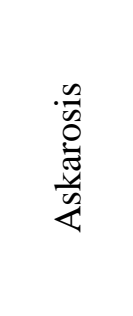 & 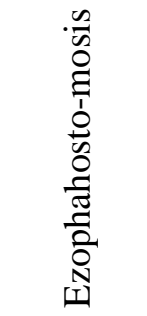 & 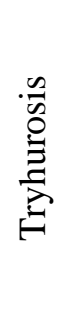 & 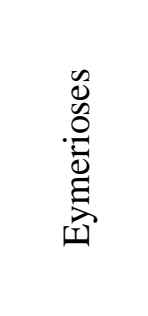 & 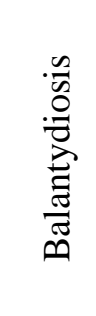 \\
\hline Fyulleborn's & 376,67 & 1373,85 & 20 & 385,71 & 330 \\
\hline Kotelnykov-Khrenov's & 5070 & 3007,14 & 20 & 5666,67 & 80 \\
\hline From the solution bishofit & 7622,5 & 1364 & - & 618 & 46,67 \\
\hline
\end{tabular}

When comparing the performance of EI for askarosis $(50 \%)$, ezophahostomosis $(93,8 \%)$ and eymerioses $(62,5 \%)$ of pigs was the most effective flotation method using a solution bishofit; by balantidiosis (56,3\%) - Kotelnykov-Khrenov's method. Eggs of tryhuryses (12,5\% of samples) showed only the application of flotation methods of Fyulleborn and Kotelnykov-Khrenov. The Fyulleborn's method was the

However, given the values of intensity of infestation by protozooses and helminthoses of pigs using different flotation methods (Table 2), the highest number of eggs of askaryses (7622,5 EGF) found in the application solution bishofit; by ezofahostomosis (3007,14 EGF) and eymerioses (5666,67 OGF) - Kotelnykov-Khrenov's method; by balantidiosis (330 CGF) - Fyulleborn's method.

Tryhuroses in pigs number of eggs in $1 \mathrm{~g}$ of feces was 20 for use as a Fyulleborn's method and Kotelnykov-Khrenov's method.

So intravital flotation coproovoscopical methods of laboratory diagnosis of Fyulleborn, KotelnykovKhrenov and using solution bishofit is effective by helminthoses and protozooses of pigs caused by infection askarosis, ezophahostomosis, tryhurosis, eymerioses and balantidioses. However, to improve diagnosis of parasites in pigs material should be investigated simultaneously by several methods.

\section{Conclusions:}

1. Established that the most common parasites of pigs in the Poltava region is askarosis, ezophahostomosis, tryhurosis, eymerioses and balantidiosis.

2. Most effective quality coproovoscopical method for diagnosing askarosis, ezophahostomosis and eymerioses of pigs was method using a solution bishofit and balantidiosis - Kotelnykov-Khrenov's method.

3. High diagnostic efficiency for tryhurosis pigs showed Fyulleborn's method and KotelnykovKhrenov's method. 


\section{REFERENCES}

1. Арнастаускене Т. В. Кокцидии и кокцидиозы домашних и диких животных Литвы / Т. В. Арнастаускене. - Вильнюс : Мокслас, 1985. - C. 7-15; 25-26; 69-101.

2. Балашов Ю. С. Экология непаразитических стадий жизненного цикла иксодовых клещей / Ю. С. Балашов // Паразитол. сборник. - 1989. C. 56-81.

3. Березовский A. В. Основные болезни свиней и современные средства для их лечения и профилактики: справочник / А. В. Березовский, А. И. Поживил, В. П. Литвин. - К. : ПП «Грета», 2008. - С. 30-31; 39-43; 64-79.

4. Воробьев В. В. Изменение вирулентности и длительности пребывания Babesia divergens (B. bovis) в организме крупного рогатого скота / В. В. Воробьев, А. Х. Гайдуков, И. В. Касаткина // Инваз. болезни с.-х. животных и птиц : Сб. научн. тр. Ленинградского ветинститута. - Л., 1987. - C. 19-22.

5. Герасимчик В. А. Сравнительная эффективность копроскопических методов исследований при эймериидозах плотоядных / В. А. Герасимчик // Ветеринария. - 2003. - № 7. - С. 27-30.

6. Герасимчик В. А. Кишечные паразитозы пуш- ных зверей : Монография / В.А. Герасимчик. Витебск : ВГАВМ, 2009. - С. 8-11.

7. Локтева И. М. Усовершенствование методики лабораторной диагностики кишечных кокцидиозов / И. М. Локтева， А. В. Сопиль, А. В. Лезин // Лабораторная диагностика. - 1999. - № 1. C. 33-34.

8. Прискока В.А. Діагностика змішаних інфекцій (паразитоценозів) у шлунково-кишковому тракті / В. А. Прискока, Ф. С. Вабіщевич, В. М. Горжеев [та ін.] // Ветеринарна медицина України. - 1998. - № 8. - C. 18 .

9. Трусова О.С. Санитарные условия содержания и гельминтозы у свиней / О. С. Трусова // Актуальные проблемы вет. хирургии. - 1997. C. 97-98.

10. Ямщииков В. Н. Распространение и терапия кишечных гельминтозов свиней : автореф. дис. ... канд. вет. наук: спец. 03.00.19 «Паразитология, гельмінтологія» / В. Н. Ямщиков. - Н. Новгород, 2003. - 20 с.

11. Эпизоотология кишечных нематодозов свиней в базовых хозяйствах / А. А. Савельев, О. Л. Куликова, А. В. Аринкин [и др.] // Вет. патология. - 2006. - № 1. - С. 71-74. 